\title{
Regional biomass burning trends in India: Analysis of satellite fire data
}

\author{
L K Sahu ${ }^{1, *}$, Varun Sheel ${ }^{1}$, Kumud Pandey ${ }^{2}$, Ravi Yadav $^{3}$, P Saxena ${ }^{1}$ and Sachin Gunthe ${ }^{4}$ \\ ${ }^{1}$ Space and Atmospheric Sciences Division, Physical Research Laboratory (PRL), Navrangpura, \\ Ahmedabad 380 009, India. \\ ${ }^{2}$ Applied Science Department, FIT Engineering College, Mawana Road, Meerut, India. \\ ${ }^{3}$ Department of Physics, Mohanlal Sukhadia University, Udaipur 313 001, India. \\ ${ }^{4}$ Department of Civil Engineering, Indian Institute of Technology, Chennai, India. \\ *Corresponding author.e-mail: lokesh@prl.res.in; l_okesh@yahoo.com
}

The results based on the analysis of satellite fire counts detected by the Along-Track Scanning Radiometer (ATSR) sensors over different regions of India during 1998-2009 have been presented. Generally, the activities of open biomass burning show large spatial and temporal variations in India. The highest and lowest values of monthly fire counts were detected during the periods of March-May and July-September, respectively over different regions of India. The activities of biomass burning in two central states of Madhya Pradesh and Maharashtra were the highest and together accounted for about 25-45\% of total annual fire counts detected over India during the study period. However, in opposite phases, the rainfall and fire count data show strong seasonal variation. In addition to large regional and seasonal variations, the fire data also show significant year-to-year variation. The higher annual fire counts exceeding the mean of entire period by about $16 \%$ and $43 \%$ were detected during the two periods of 1998-2000 and 2007-2009, respectively. We have estimated normalized anomaly of annual fire count data which shows large positive departures from long-term mean for the years 1999, 2007, 2008 and 2009, while negative departures for the years 2002, 2003 and 2005. Consistently, the mixing ratio of carbon monoxide (CO) typical peaks during winter but extended to pre-monsoon season during extensive fire years. The annual data over the entire region of India show lesser positive trend of about $3 \% \mathrm{yr}^{-1}$. The inter-annual variation of fire count over entire India follows the trend in the ENSO Precipitation Index (ESPI) but shows opposite trend to the multivariate ENSO Index (MEI).

\section{Introduction}

According to the widely accepted definition, biomass burning includes forest and grassland fires of both human and natural origin and the burning of agricultural or crop residue in fields (Levine 2000; Bond et al. 2004; Sahu et al. 2012). Biomass burning is a global phenomenon which has significant implications for climatic change, environment, human health, biodiversity, and land cover. Globally, about
$90 \%$ of biomass burning is believed to be humaninitiated and about $10 \%$ by atmospheric lightning. In recent years, it has become a major issue because humans have dramatically influenced biomass burning for agricultural needs and economic development. In most of the recent studies, the combustion of biofuels for residential cooking and heating are not treated as biomass burning (Venkataraman et al. 2006). Biomass burning has been a topic of scientific interest from many years due to the

Keywords. India; biomass burning; ATSR; seasonal; regional. 
implications for climatic change as a result of landscape change, loading of aerosols and trace gases in the atmosphere (Crutzen and Andreae 1990).

Comprehensive modelling-based emission estimates of various trace gases and aerosols indicate major or significant contributions from biomass burning sources on global scale (van der Werf et al. 2006, 2010). In the tropical regions, the activities are particularly widespread accounting for about 80\% of global biomass burning (Hao and Liu 1994; Christopher et al. 1996; Folkins et al. 1997). For some species like carbon monoxide (CO) and volatile organic compounds (VOCs), the biomass burning emissions account for $20-30 \%$ of the total emissions in Asia (Streets et al. 2003). The biomass burning emissions in India contribute substantially to the budgets of various aerosols and gaseous species in Asia (Streets et al. 2003; Bond et al. 2004). According an estimate between 1995 and 2000 , the open burning sources contributed about $25 \%$ to black carbon, organic matter, and CO emissions in India (Venkataraman et al. 2006).

The updraft of biomass smoke by tropical convection may significantly impact the climate dynamics. The modelling studies of transport explain the role of injection into the tropical upper troposphere on regional and continental scales (Andreae and Merlet 2001). In addition, fire-induced convection could be another key factor that contributes to the uplifting of fire emissions. Quantification of the amount of these species transported from India and other continental regions of Asia to the remote Indian Ocean was a major objective of the Indian Ocean Experiment (INDOEX) campaign (Lelieveld et al. 2001; Sahu et al. 2006, 2011). The in-situ measurement and model studies of aerosols and trace gases indicate significant contribution from biomass burning sources in different parts of India (e.g., Kharol and Badarinath 2006; Sahu and Lal 2006; Lal 2007; Kumar et al. 2012). Satellite-based fire data has been to characterize the variability of biomass burning during the past several decades (e.g., Dozier 1981; Kaufman et al. 1998; Giglio et al. 2003; Wooster et al. 2005). Theoretically, remote sensing data should provide the capability to directly quantify emissions of gaseous and particulate species, but in practice this requires determination of the source of emissions which involves complex inversion and geochemical transport modelling (Mieville et al. 2010). In detail, parameters like amount of biomass available, mass fraction of carbon in fuel, combustion factor and combustion averaged emission factor are required to estimate the emission inventory. These parameters are known to exhibit large spatial and temporal variations and inadequate information increases the uncertainty in the emission estimates (Sahu and Sheel 2014). The amount of biomass consumed has been derived mainly from the active fire detected by the Tropical Rainfall Measuring Mission (TRMM), Visible and Infrared Scanner (VIRS), Along-Track Scanning Radiometer (ATSR), and MODerate resolution Imaging Spectroradiometer (MODIS) active fire data (van der Werf et al. 2006 and references therein). Nonetheless, the model simulations rely on the inventory data to explain the observed features in the distribution of various key constituents in the atmosphere. The activities of biomass burning are mostly uncontrolled and pose a great deal of challenge to estimate the reliable emissions of aerosols and trace gases (Streets et al. 2003). However, such inventories are available with several key limitations, viz., large uncertainty and poor spatial resolution depending on the species of interest. Therefore, use of biomass burning inventory data in the model simulations has been treated subjectively. In contrast, the anthropogenic emission processes are reasonably well parameterized and enable less uncertain emission estimate of many gaseous and particulate species. Lack of information regarding the cause, location and timing of biomass burning are the major factors that cause uncertainty in the emission estimates of trace gases and aerosols. Additionally, the large uncertainties associated with burned biomass estimates, and in particular those associated with open burning, are caused by the uncertainty inherent in burned areas, fuel loads, combustion factors, and emission factors (Ito and Penner 2004). The largest differences between the model and observation in India were seen during the intense biomass burning activity and are related to the uncertainties in the emission data (Kumar et al. 2012). The long-term studies characterizing the variation of regional biomass burning in India are rare.

In this study, we have discussed the spatial and temporal variations of biomass burning over India. We have analyzed the regional, seasonal and interannual patterns of fire count data detected over India during the years 1998-2009. This study clearly reflects about the factors/sources involved in biomass burning by different statistical analysis. For this purpose, we have used the ATSR fire count data in the present study. The discussion related to the emissions of specific aerosols and trace gases are beyond the scope of this paper and the results related only to the fire events have been presented. On global scale, the ATSR-World Fire Atlas (WFA) monthly fire counts are about $40 \%$ smaller than the related MODIS-Terra fire products (Arino et al. 2012). The correlation coefficient between ATSR-WFA and MODIS datasets is very high (0.87). The scope of this paper is remarkable as it summarizes not only spatial but also temporal variation of biomass burning in different parts of India. 


\section{Data and analysis}

The European Space Agency (ESA) ATSR-WFA project provides a global fire data detected by the ATSR-2 and Advanced Along-Track Scanning Radiometer (AATSR) sensors (Arino et al. 2005, 2007). The global fire count map represents the location and time for which the emitted radiances exceed the criteria values in the middle-infrared (MIR) band centered at $3.7 \mu \mathrm{m}$. The algorithms namely ALGO1 and ALGO2 are based on the anomalous night-time brightness temperature (BT) threshold exceeding 312 and $308 \mathrm{~K}$, respectively. The AATSR and ATSR-2 data are available with $1 \mathrm{~km} \times 1 \mathrm{~km}$ of spatial resolution. The ATSR dataset contains a number of events from heat sources other than vegetation fire like flares from oil-gas industrial sites, crude oil production and volcanoes. However, for this study, we assume that contributions from such activities other than vegetation fires are negligible over India (Casadio et al. 2012). In any case, the trend analysis of biomass burning will not be affected as fire counts from other activities are typically fixed in location and show less variation with time. The inherent drawback with the algorithm ALGO2 is the dependence of the $3.7 \mu \mathrm{m}$ BT values from the warm surface, i.e., from the nonburning activities. Another drawback with ATSR is the night-time overpass with the fact that biomass fire activity peaks in the afternoon due to both human activity and meteorological conditions. Cloud coverage could be also a source of uncertainty as it prevents the detection of surface fires. Despite their several shortcomings, the ATSR fire count data provide the best current information on the seasonal and spatial variations of biomass burning activity in many parts of the world. However, the ATSR data itself does not provide the information about the type of material/vegetation specific to the fire count detected unless specified from other sources or observations. The fire count detection has been employed in numerous studies for a variety of applications (Duncan et al. 2003). Emissions of $\mathrm{CO}$ and its variability with the biomass fire events over India have been demonstrated by Singh et al. (2009). The usefulness of Advanced Very High Resolution Radiometer (AVHRR) and ATSR fire counts as well as burned area estimates using SPOT (Satellite Pour Observation de la Terra) imagery during the 1997 Indonesian fire season has been demonstrated (Legg and Laumonier 1999). In this study, we have used the fire count data derived by algorithm ALGO2 which also represents the small intensity biomass fires. Additional details of the ATSR fire count detection and related methodologies can be found elsewhere (Buongiorno et al. 1997; Arino et al. 2001). We have also used
CO data from the Model for Ozone and Related Tracers, version 4 (MOZART-4). In our institute (Physical Research Laboratory), we run the model on the 3 Terraflop HPC Linux cluster with 20 nodes. A typical one year run takes about $12 \mathrm{hrs}$ of time.

\section{Results and discussion}

\subsection{Regional and seasonal variation}

The yearly fire count maps of India from 1998 to 2009 are shown in figure 1 . In each map, the fire count data has been colour-coded for the respective month of the year. The fire map shows large spatial and seasonal variations during each year. The events of biomass burning can be predominantly located in the central parts, downhill of Himalayas, and eastern regions of India. The moderate activities of biomass burning can be noticed over the southern peninsular region of India. However, lesser events of biomass burning in the northwestern region (except Punjab state) of India are quite evident in the annual fire count map of each year. The present result is consistent with the fact that the western part of the Indo-Gangetic Plain (IGP) has the highest crop waste availability followed by central and peninsular India. Whereas, central India shows highest forest fire activities followed by the eastern part of IGP and the northeastern part of India (Venkataraman et al. 2006). In tropical countries like India, fires are mostly related to deforestation, shifting cultivation and clearance of agricultural residue (Singh and Panigrahy 2011). In figure 1, some fire points particularly in the oceanic region near Mumbai represents natural gas flares and we have not treated such points in the discussion related to the variation of biomass burning sources. Moreover, the visualization of fire points through dots in figure 1 may hide other colours depicting the months due to very nature of overlay of points. Therefore, we suggest referring of figure 2 for exact quantification of monthly fires in different states of India.

The map for the year 1999 shows extensive biomass burning along the foothills of the Himalayas and northeast region of India. Although it represents small geographical area, the fires in northeast region also make substantial contribution. In most parts of India, the events of biomass burning occur during the pre-monsoon season. However, in some regions, the biomass burning remains active during the winter season. The biomass burning activities in the two central states of Madhya Pradesh (including Chhattisgarh) and Maharashtra were highest among all the states in India. In the annual fire count data of India during 1998-2009, the biomass activities in these states accounted 

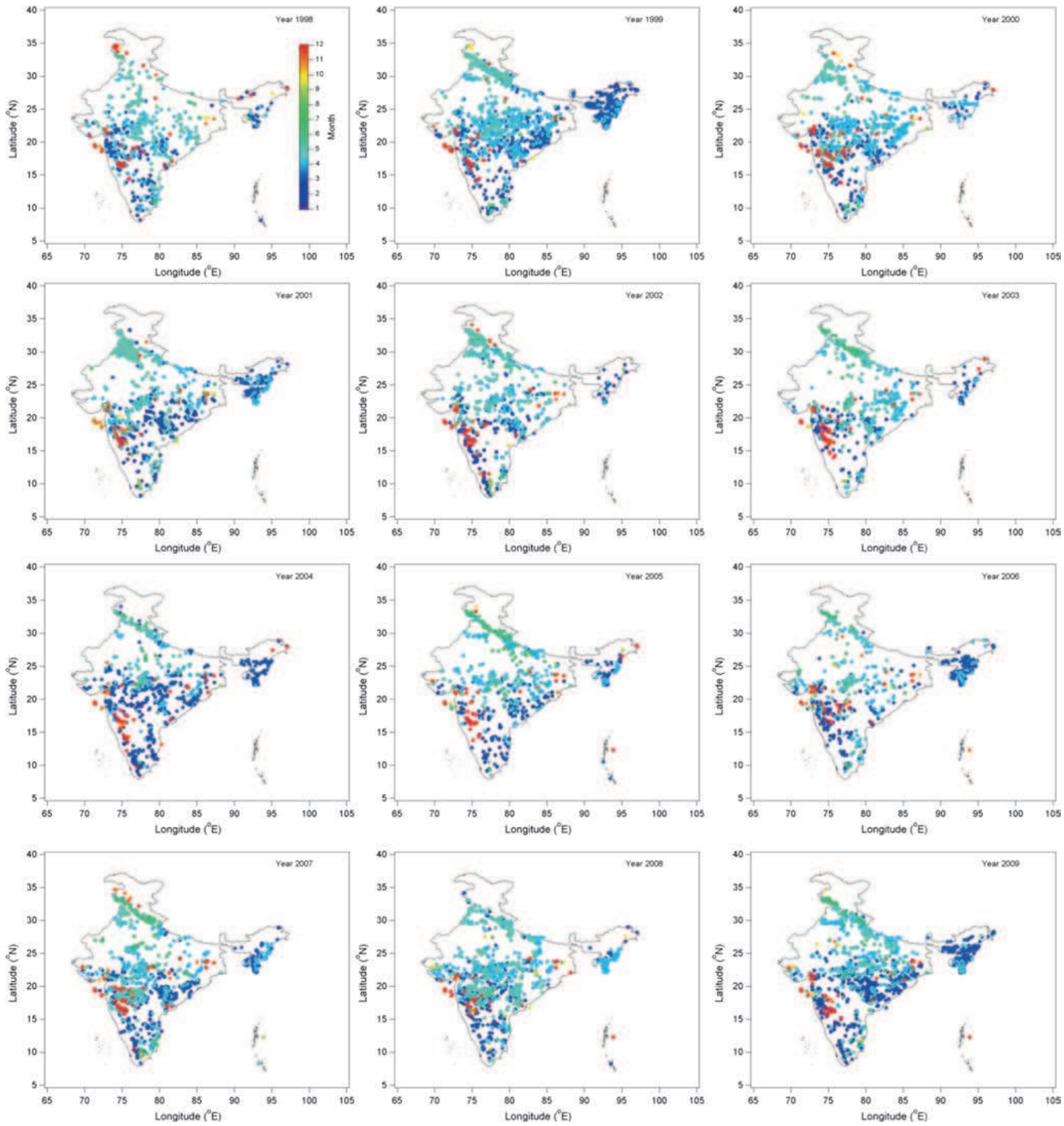

Figure 1. The ATSR-WFA fire count maps of India from 1998 to 2009. The fire counts are colour-coded for the respective month of the year.

for about $25-45 \%$ with a mean value of $36 \pm 6 \%$ of total fire count. The annual variation based on the monthly mean of fire count data detected for the different states of India during 1998-2009 are shown in figure 2. In most of the states, the activities of biomass burning show clear seasonality with a peak during March-April (summer) period. This is consistent with another study over India for the year 2013 reporting more than $70 \%$ of total fires during March-April period. However, the peak activities in the northwest states of Haryana, Punjab and Rajasthan were detected in the month of May. The moderate activities were detected during March-May period in many parts of India. It was a known fact that Rajasthan faced severe drought conditions. However, it is still uncertain if this was linked to ENSO conditions. For example, unusually low annual rainfall of $220 \mathrm{~mm}$ was recorded in 1998. Giriraj et al. (2010) also report high occurrence of fires particularly over 


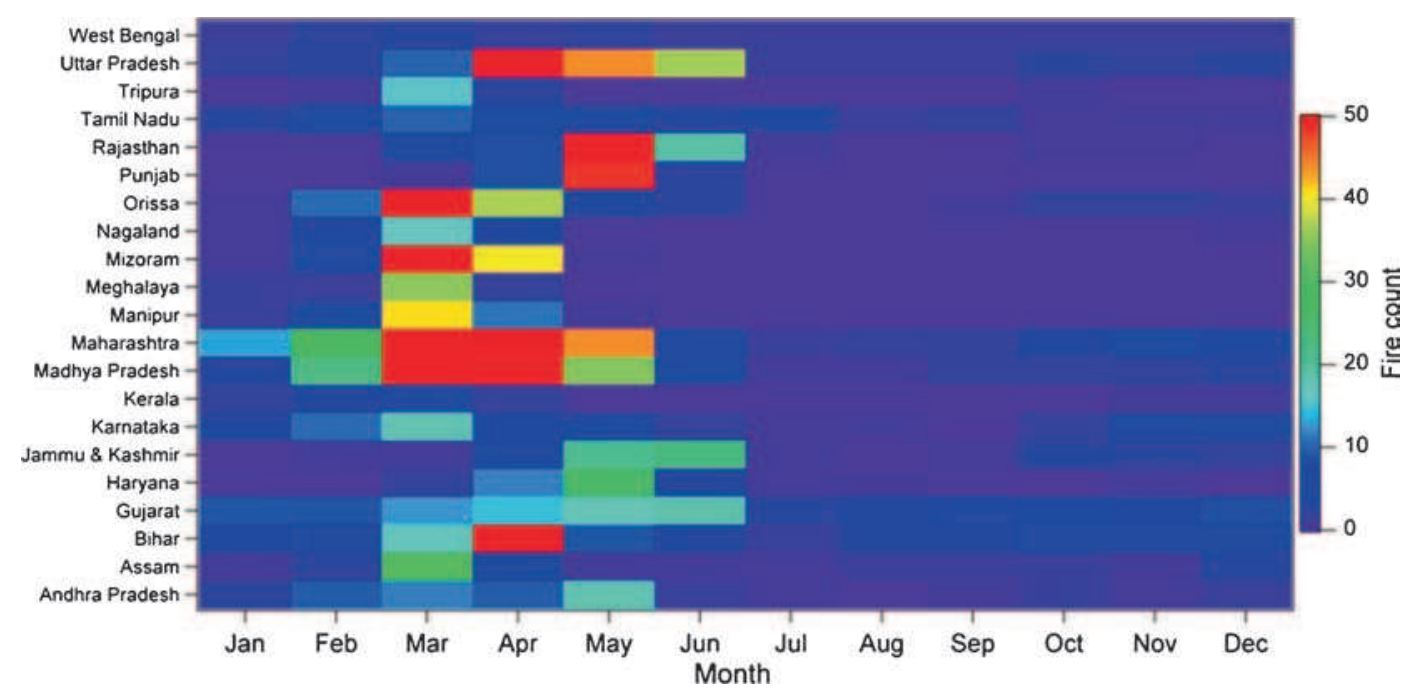

Figure 2. Annual variation based on monthly means of fire counts detected for the different months during $1998-2009$ in different states of India.

eastern Rajasthan during May 1998. Primarily, this has been caused by prolonged dry seasons and droughts and hence increasing the loading of dry biomass. For example, some events during the month of June were also detected in the sates of Gujarat, Uttar Pradesh, Jammu and Kashmir, etc. The seasonality of fire data in the southern states of Andhra Pradesh, Karnataka, Kerala and Tamil Nadu does not show strong peaks as moderate activities were detected from the month of January to June. On average, the fires during March-May accounted for more than $75 \%$ of total annual fires detected in India.

There can be several factors like meteorology, post-harvest burning and land use practices leading to the regional and seasonal variations in fire count data over India (Habib et al. 2006). Biomass burning seasonal cycle with high in pre-monsoon season and low in monsoon season is because of highest agricultural waste burning and highest rainfall, respectively. Two seasonal crops known as rabi (wheat, burley, mustard, etc.) and kharif (rice, millets, pulses, groundnut, cotton, sugarcane, etc.) are harvested during late winter and monsoon seasons, respectively. Moreover, the forests were cleared during late December, January while the slash and burn started from February till May. The peak burning occurs during March. Therefore, the post-harvesting agriculture residue burning peaks in May (for rabi crops) and in October (for kharif crop) in the IGP region. In central India, agricultural residue burning occurs during JanuaryApril and October-December, while in peninsular India, the crops residue burning takes place during February-March consistent with the harvesting months (Duncan et al. 2003). This observation is similar to the previous studies which attribute agricultural residue burning to the total cropped areas in one of the regions of India, Punjab (Singh and Panigrahy 2011), while the forest fire peaks in the pre-monsoon season in India irrespective of region. We have used the monthly rainfall and fire count data over India during 1998-2009 (figure 3a). The monthly mean mixing ratios of $\mathrm{CO}$ at surface and $300 \mathrm{hPa}$ levels obtained from the MOZART-4 model over India $\left(7-37^{\circ} \mathrm{N}, 69-97^{\circ} \mathrm{E}\right)$ for the years 2001-2008 are also plotted. The surface mixing ratio of CO clearly shows seasonality with highest during the winter season. However to be exact, this feature does not match with the seasonality in the biomass burning events. One of the possible reasons could be the compressed PBL depth favouring accumulation of pollutant near the surface during winter. Although the biomass burning peaks during the pre-monsoon, the surface level $\mathrm{CO}$ is slightly lower than the expected. In this season, the surface temperature is very high compared to that of winter months and hence provides favourable conditions for the convective updraft motion. In tropical regions, the atmospheric convection is an important force for the transport of airmass from surface to the upper troposphere (Sheel et al. 2014). However, in the presence of convection, emission may be high, but the buildup of higher levels in the atmospheric is inhibited to efficient ventilation. We have also shown in $\mathrm{CO}$ at $300 \mathrm{hPa}$, which show opposite seasonality to that of surface level CO. To some extent, this supports the role of convection in pre-monsoon months. Nonetheless, in spite of the role of convection, the enhancements in surface CO particularly during extensive fires in the pre-monsoon months of 2004 and 2007 can be clearly noticed. For example, the mean mixing ratios of $\mathrm{CO}$ were 282 and 350 ppbv during 

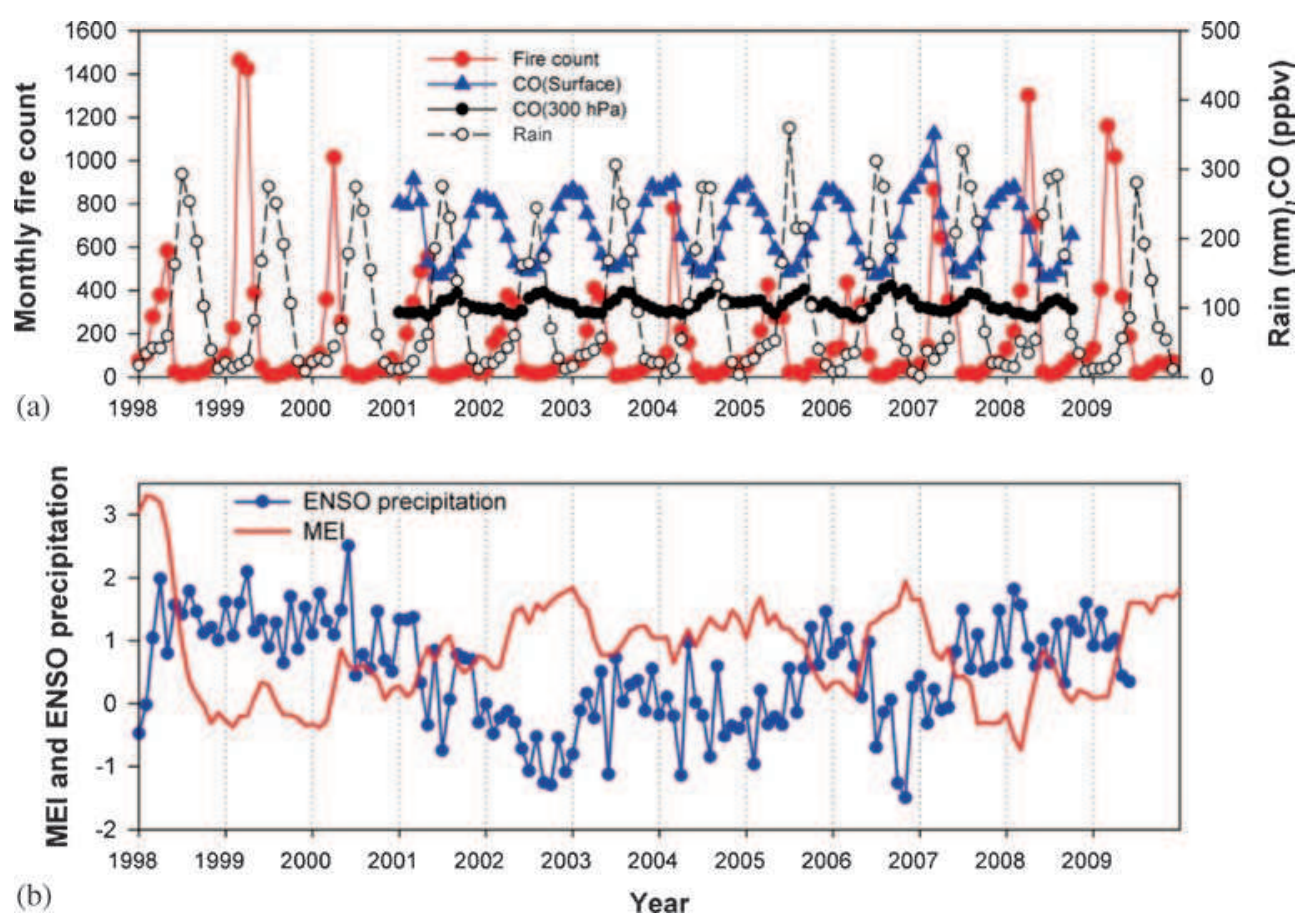

Figure 3. Long-term monthly variations of fire count, total rainfall, CO mixing ratio, MEI and ESPI indices during the period of 1998-2009 over India.

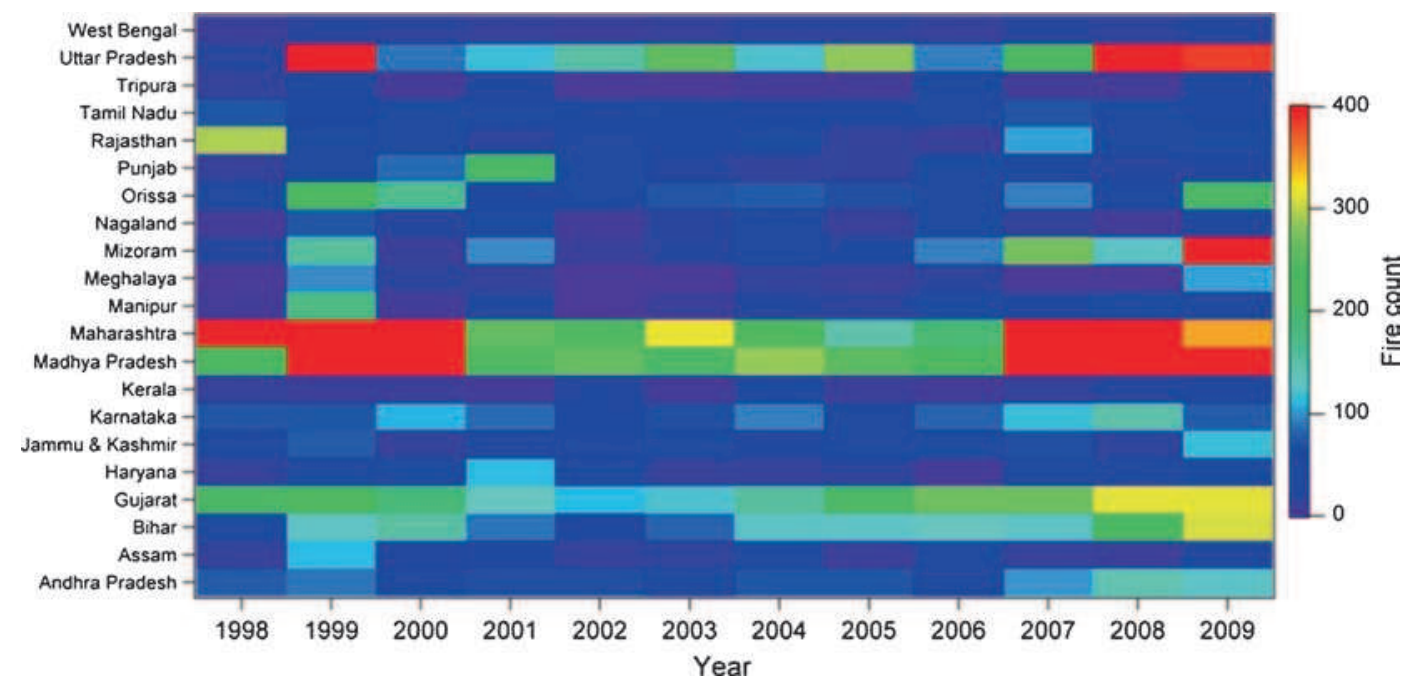

Figure 4. The state-wise annual fire trends during the years 1998-2009.

March-April period of 2004 and 2007, respectively. These values of $\mathrm{CO}$ were significantly higher than the mean value (241 ppbv) calculated for the premonsoon period of 2001-2008. Therefore, presence of exceptionally high $\mathrm{CO}$ can be clearly noticed even though dilution due to convection. The rainfall and fire count data show strong seasonal variation but were opposite in phase to each other. From the month of February to March, the activities of biomass fire were intense but rainfall was almost negligible across the India. On the contrary, the biomass burning activities were negligible but rainfall was highest during the monsoon season (July-September). The month of June may represent the transition period when both rainfall and biomass can co-exist to some extent. Cloudy conditions during rainy season can further obscure the detection of active fires by satellite-based sensors. The out-of-phase annual variations of biomass fire and rainfall suggest that the dry conditions during the late winter and pre-monsoon seasons facilitate the biomass burning activity, whereas the opposite is true in monsoon season. Due to vast geographical and climatic variations, the determination of exact 
causes of fires on very small spatio-temporal domain requires further information.

\subsection{Inter-annual variation}

The annual fire count data detected over different states of India during the years 1998-2009 are plotted in figure 4 . The annual fire count data for almost all the states show large year-to-year variation, therefore the inter-annual trend is difficult to discern. However, the higher annual fire counts exceeding the mean of entire period by about $16 \%$ and $43 \%$ were detected during the periods of 19982000 and 2007-2009, respectively. The seasonality of biomass fires over India is mainly determined by the harvesting practices as burning of agricultural residue makes major fraction of biomass which is subject to seasonal land clearance. However, periods of anomalously high fire counts during 19982000 and 2007-2009 were detected over India. In figure $3(\mathrm{~b})$, we have plotted the monthly time series of MEI and ESPI data to see the relation if El Niño and La Niña conditions play any role in the fire anomaly. The events of anomalously high fire counts were associated with sharp increase in MEI and ESPI parameters. However, irrespective of prevailing El Niño or La Niña conditions, events of sudden increase particularly of ESPI were associated with increased fire counts. In turn, these climatic events could have led increased availability of dry biomass material in the field and forest over
India. Overall, the exact role of El Niño or La Niña conditions on the biomass fire is very complex.

On the other hand, the annual data during the years 2001-2006 were lower by about 30\% compared to the mean of entire study period. The range of inter-annual variation varied from region to region and was particularly large in the three major states of Madhya Pradesh, Maharashtra and Uttar Pradesh. The total annual fire count data for different states of India are also presented in table 1 . To deduce the underlying features of interannual variation, we have estimated the normalized anomaly based on the total annual data for all the states of India. We have computed the normalized anomaly of fire count data using following formula.

$$
\text { Normalized anomaly }=\frac{(X-\text { Mean })}{\mathrm{SD}}
$$

where $X$ is the total annual fire count data for each state, while 'Mean' and 'SD' are the long-term (1998-2009) average and standard deviation, respectively. The normalized anomaly is a dimensionless parameter. The highest normalized anomaly corresponds to the highest departure in annual fire data from the long-term mean. The time series plots of normalized anomaly for the different states are shown in figure 5 . The normalized anomaly varied in the range of -1.7 to 3.01 depending on the region. As expected, the higher positive anomalies for many states were in the years 1999 and 2009. Whereas, the significant negative anomalies for almost all

Table 1. The annual fire count data detected over different states of India during the years 1998-2009.

\begin{tabular}{|c|c|c|c|c|c|c|c|c|c|c|c|c|}
\hline & 1998 & 1999 & 2000 & 2001 & 2002 & 2003 & 2004 & 2005 & 2006 & 2007 & 2008 & 2009 \\
\hline Andhra Pradesh & 78 & 90 & 66 & 70 & 69 & 42 & 72 & 72 & 49 & 103 & 145 & 127 \\
\hline Assam & 13 & 113 & 24 & 29 & 13 & 16 & 40 & 7 & 32 & 14 & 7 & 52 \\
\hline Bihar & 36 & 125 & 153 & 89 & 56 & 79 & 127 & 127 & 130 & 125 & 213 & 307 \\
\hline Gujarat & 211 & 236 & 189 & 135 & 115 & 123 & 156 & 209 & 266 & 265 & 310 & 316 \\
\hline Haryana & 11 & 48 & 42 & 115 & 41 & 13 & 13 & 16 & 3 & 32 & 32 & 42 \\
\hline Jammu \& Kashmir & 32 & 78 & 12 & 34 & 65 & 42 & 23 & 48 & 43 & 68 & 15 & 118 \\
\hline Karnataka & 71 & 74 & 110 & 84 & 54 & 70 & 91 & 31 & 80 & 119 & 148 & 75 \\
\hline Kerala & 13 & 10 & 7 & 4 & 26 & 5 & 31 & 10 & 3 & 14 & 26 & 30 \\
\hline Madhya Pradesh & 219 & 914 & 459 & 238 & 259 & 207 & 285 & 251 & 219 & 416 & 666 & 524 \\
\hline Maharashtra & 428 & 531 & 447 & 257 & 235 & 321 & 238 & 149 & 195 & 554 & 659 & 344 \\
\hline Manipur & 3 & 179 & 3 & 27 & 1 & 9 & 19 & 18 & 42 & 23 & 41 & 50 \\
\hline Meghalaya & 0 & 96 & 15 & 14 & 0 & 1 & 13 & 8 & 15 & 2 & 2 & 104 \\
\hline Mizoram & 22 & 158 & 8 & 96 & 7 & 19 & 38 & 53 & 94 & 270 & 124 & 517 \\
\hline Nagaland & 4 & 73 & 20 & 36 & 3 & 16 & 40 & 9 & 36 & 13 & 3 & 29 \\
\hline Orissa & 50 & 222 & 166 & 58 & 33 & 71 & 78 & 68 & 31 & 94 & 33 & 206 \\
\hline Punjab & 11 & 44 & 86 & 207 & 45 & 20 & 13 & 12 & 45 & 28 & 21 & 23 \\
\hline Rajasthan & 295 & 36 & 40 & 18 & 33 & 30 & 38 & 12 & 9 & 107 & 46 & 46 \\
\hline Tamil Nadu & 72 & 62 & 43 & 33 & 52 & 31 & 60 & 30 & 31 & 71 & 40 & 57 \\
\hline Tripura & 12 & 32 & 3 & 24 & 2 & 0 & 3 & 6 & 49 & 5 & 3 & 30 \\
\hline Uttar Pradesh & 22 & 430 & 90 & 119 & 152 & 256 & 122 & 283 & 92 & 218 & 402 & 382 \\
\hline West Bengal & 9 & 20 & 15 & 13 & 7 & 11 & 15 & 15 & 12 & 22 & 16 & 26 \\
\hline India & 1612 & 3571 & 1998 & 1700 & 1268 & 1382 & 1515 & 1434 & 1476 & 2563 & 2952 & 3405 \\
\hline
\end{tabular}




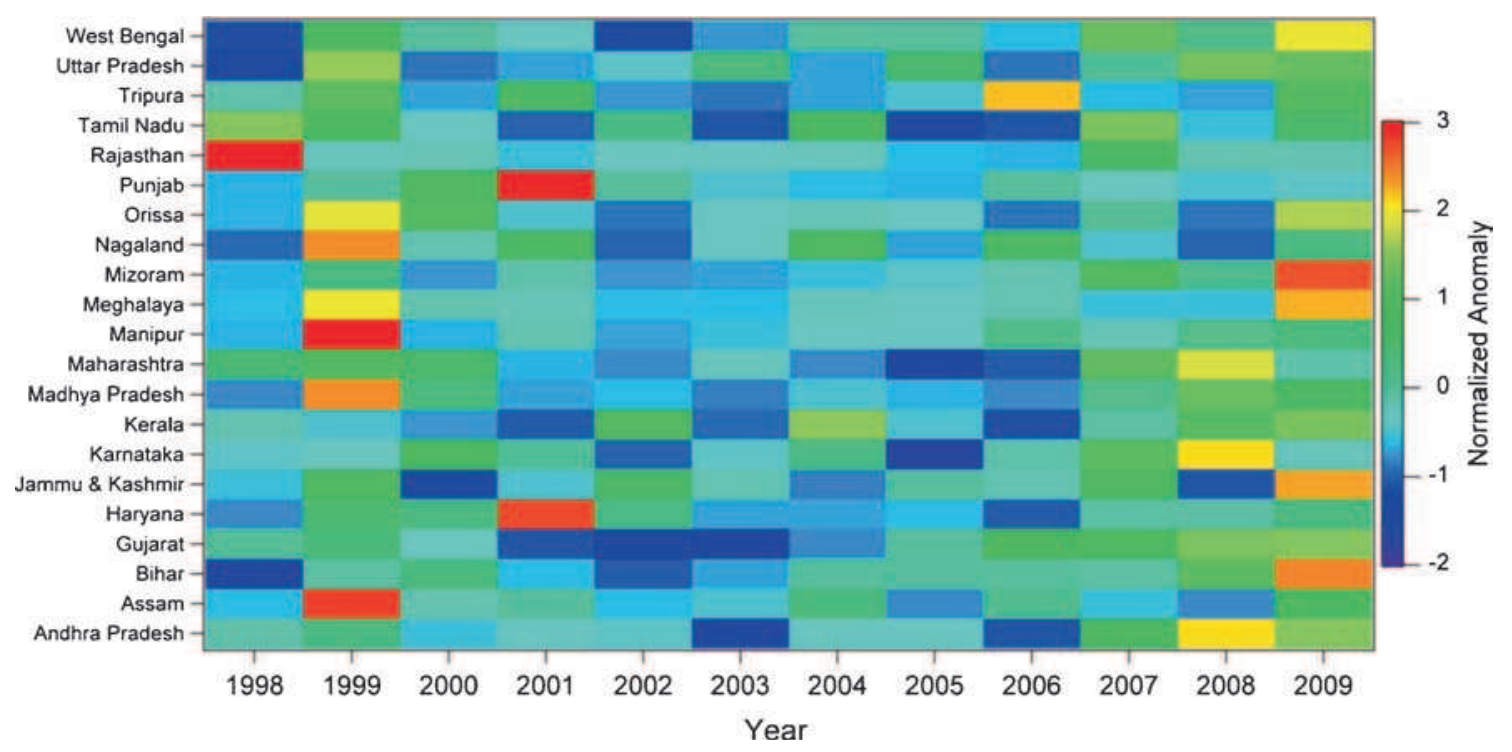

Figure 5. Time series variation of normalized anomaly for the different states.

Table 2. The annual mean normalized anomaly of fire count data over different states of India during the years 1998-2009.

\begin{tabular}{|c|c|c|c|c|c|c|c|c|c|c|c|c|}
\hline & 1998 & 1999 & 2000 & 2001 & 2002 & 2003 & 2004 & 2005 & 2006 & 2007 & 2008 & 2009 \\
\hline ndhra I & 0.13 & 0.27 & 0.53 & -0.40 & 0.434 & -1.33 & 0.33 & 0.33 & 1.09 & 0.70 & 2.10 & 1.50 \\
\hline Assam & -0.58 & 2.81 & -0.20 & -0.03 & -0.58 & -0.47 & 0.34 & -0.78 & 0.07 & -0.54 & -0.78 & 0.74 \\
\hline Bihar & -1.31 & -0.08 & 0.31 & -0.58 & -1.03 & -0.71 & -0.05 & -0.05 & -0.01 & -0.08 & 1.14 & 2.44 \\
\hline Gujarat & 0.0012 & 0.36 & -0.31 & -1.09 & -1.37 & -1.26 & -0.79 & -0.03 & 0.79 & 0.77 & 1.42 & 1.50 \\
\hline Haryana & -0.78 & 0.47 & 0.27 & 2.74 & 0.24 & -0.71 & -0.71 & -0.61 & -1.05 & -0.07 & -0.07 & 0.27 \\
\hline Jammu \& Kashmir & -0.54 & 0.99 & -1.20 & -0.47 & 0.56 & -0.20 & -0.83 & -0.01 & -0.17 & 0.66 & -1.10 & 2.31 \\
\hline Karnataka & -0.42 & -0.32 & 0.85 & 0.0027 & -0.98 & -0.45 & 0.23 & -1.73 & -0.13 & 1.15 & 2.09 & -0.29 \\
\hline Kerala & -0.18 & -0.47 & -0.76 & -1.04 & 1.06 & & 1.54 & -0.47 & & -0.09 & 1.06 & 1.44 \\
\hline Madhya Pradesh & -0.77 & 2.38 & 0.32 & -0.68 & -0.58 & -0.82 & -0.47 & -0.62 & -0.77 & 0.13 & 1.26 & 0.62 \\
\hline Maharashtra & 0.40 & 1.05 & 0.52 & -0.66 & -0.80 & -0.26 & -0.78 & -1.34 & -1.05 & 1.19 & 1.84 & -0.12 \\
\hline Manipur & -0.65 & 2.99 & -0.65 & -0.16 & -0.70 & -0.53 & -0.32 & -0.34 & 0.15 & -0.24 & 0.13 & 0.32 \\
\hline Meghalaya & -0.61 & 2.00 & -0.20 & -0.23 & - & & 26 & 39 & -0.20 & -0 & -0.56 & 2.22 \\
\hline Mizoram & -0.65 & 0.28 & -0.74 & -0.14 & -0.75 & -0.67 & -0.54 & -0.44 & -0.16 & 1.04 & 0.05 & 2.71 \\
\hline Nagaland & -0.95 & 2.40 & -0.17 & 0.61 & -0.99 & -0.36 & 0.80 & -0.70 & 0.61 & -0.51 & -0.99 & 0.27 \\
\hline Orissa & -0.63 & 1.92 & 1.09 & -0.51 & -0.88 & -0.32 & -0.21 & -0.36 & -0.91 & 0.02 & -0.88 & 1.68 \\
\hline Punjab & -0.64 & -0.04 & 0.72 & 2.93 & -0.02 & -0.48 & -0.61 & -0.62 & -0.02 & -0.33 & -0.46 & -0.42 \\
\hline Rajasthan & 3.01 & -0.30 & -0.24 & -0.53 & -0.33 & -0.37 & -0.27 & -0.60 & -0.64 & 0.61 & -0.17 & -0.17 \\
\hline Tamil Nadu & 1.48 & 0.85 & -0.35 & -0.98 & 0.22 & -1.11 & 0.73 & -1.17 & -1.11 & 1.42 & -0.54 & 0.54 \\
\hline Tripura & -0.13 & 1.13 & -0.70 & 0.63 & -0.76 & -0.89 & -0.70 & -0.51 & 2.21 & -0.57 & -0.70 & 1.01 \\
\hline Uttar Pradesh & -1.41 & 1.58 & -0.91 & -0.70 & -0.45 & 0.31 & -0.67 & 0.51 & -0.89 & 0.03 & 1.38 & 1.23 \\
\hline West Bengal & -1.12 & 0.90 & -0.02 & -0.38 & -1.49 & -0.75 & -0.02 & -0.02 & -0.57 & 1.27 & 0.17 & 2.01 \\
\hline India & -0.60 & 1.89 & -0.15 & -0.47 & -0.95 & -0.82 & -0.69 & -0.67 & -0.67 & 0.52 & 1.00 & 1.61 \\
\hline
\end{tabular}

the states were estimated for the year 2005. The positive anomalies were mostly due to the fires in the northwest (e.g., Rajasthan, Punjab, Haryana, etc.) and northeast regions (e.g., Assam, Manipur, Mizoram, etc.). Based on the data for all India, the large positive departures from the long-term mean were during the years 1999, 2007, 2008 and 2009. While the annual fire counts during 2002, 2003 and 2005 show large negative departures. The normalized anomalies for the different regions of India are given in table 2 .

It is an uncertain task to determine the longterm trend of fire counts which show large regional, seasonal, and inter-annual variations. The highest positive trend of about $16 \% \mathrm{yr}^{-1}$ with respect to long-term mean has been estimated for the month of June but trends for April and May are not clear or negligible. The moderate positive trends in the 


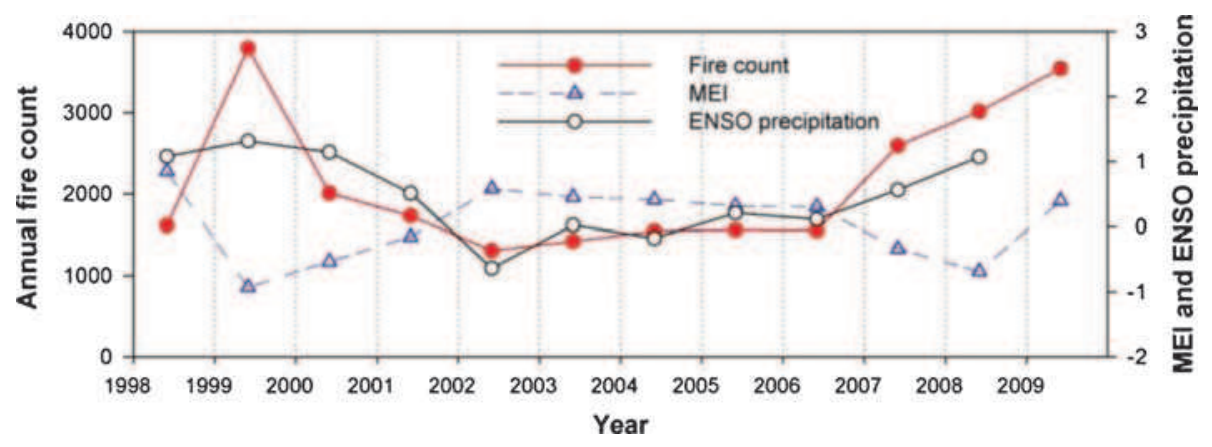

Figure 6. Time series variation of annual fire count over India, MEI and ESPI parameters during 1998-2009.

range of $3-9 \% \mathrm{yr}^{-1}$ were estimated for the remaining months. Based on the total annual data, the state-wise negative trends of $2-13 \% \mathrm{yr}^{-1}$ were estimated for Rajasthan, Punjab, Assam, Haryana, Manipur, Nagaland, Orissa and Tamil Nadu in decreasing order, respectively. On the other hand, the positive trends of $2-21 \% \mathrm{yr}^{-1}$ were estimated for the states of Mizoram, Bihar, Kerala, Uttar Pradesh, Gujarat, Andhra Pradesh, Jammu \& Kashmir, West Bengal, Meghalaya, Karnataka and Tripura in decreasing order, respectively. However, no clear long-term trends were seen in the fire counts detected over two central but major states of Madhya Pradesh and Maharashtra. Overall, the annual data over the entire region of India show a positive trend of about $3 \% \mathrm{yr}^{-1}$.

Tropical climate dynamics related to El Niño and La Niña have been known to greatly impact many parts of south Asia. The coupled phenomena of El Niño-Southern Oscillation (ENSO) result from the warming and cooling of central and eastern Pacific Ocean. The ENSO, parameterized as the multivariate ENSO Index (MEI), is computed based on six different variables, viz., sea level pressure, wind components, sea surface temperatures (SST), air temperatures, and cloudiness fraction of the sky. The extreme weather events like flood, drought typhoon, forest fires, etc., in many regions of the world were related to ENSO. Typically, the warm-phase of ENSO is characterized by rainfall deficit in South Asia. The ENSO Precipitation Index (ESPI) is a precipitation-based scale to estimate the gradient of rainfall anomalies (Curtis and Adler 2000). In this study, we have used the MEI and ESPI data from NOAA (http://www.esrl.noaa. gov/psd/data/correlation/mei.data). The time series plots of annual fire count over India, MEI and ESPI parameters for the period of 1998-2009 are plotted in figure 6 . The annual fire count data over India shows negative and positive correlations with MEI and ESPI, respectively. From 1999 to 2002, the fire count and ESPI show steady decline but accompanied by gradual increase in the MEI. But from 2003 to 2006, the fire count and ESPI show slightly increasing trends but decline in the MEI. The strong increasing trends in fire count and ESPI during 2006-2008 were accompanied by significant decline in the MEI.

\section{Summary}

In this region, rice (kharif) crop is usually grown in wet summer season (sowing: May-June and harvesting: October-November) and wheat (rabi) crop in the dry winter season (sowing: NovemberDecember and harvesting: March till May). To clear the land for next crop, farmers burn the left one residues on field (open burning). The reason for burning of agricultural residues can be:

- manual harvesting and threshing of rice/wheat involve high labour costs;

- use of combines allows rapid field preparation for the next crop, however, it leaves large amount of residues on field;

- there is no significant income-generating alternate use of rice residues and

- burning residues is a quicker way to clear the fields for the next crop.

In this study, the results of satellite fire count data detected over different regions of India during years 1998-2009 have been presented. We have used the ATSR fire count data from the European Space Agency (ESA) ATSR-WFA project. The fire counts representing the activities of open biomass burning show large regional and temporal variations across India. The monthly fire data show the highest number events of biomass burning during summer season as compared to monsoon season. The biomass burning events in two central states of Madhya Pradesh and Maharashtra were particularly high and together accounted for about 25-45\% of total annual fire count detected over India during the study period. As expected, the rainfall and fire count data show strong seasonal cycles with opposite in phases but no quantitative relation could be determined between their annual 
values. The annual fire counts substantially exceeding the mean of entire period were detected during the two periods of 1998-2000 and 20072009. However, the normalized anomaly varied in the range of -1.7 to 3.01 , depending on the region. For entire India, the normalized anomaly of annual fire count data show large positive departures for the years 1999, 2007, 2008 and 2009, but negative departures for years 2002, 2003 and 2005. The contributions of forest fire and agricultural waste burning in the inter-annual variation of fire count over India need to be determined.

\section{Acknowledgements}

The ATSR World Fire Atlas data have been taken from Ionia products of European Space Agency (ESA) produced from remote sensing data (http:// earth.esa.int). The rainfall data for India was taken from the web (http://iridl.ldeo.columbia.edu/SOUR CES/.IITM/.All_India/.Rainfall/). We are thankful to the IMD, Government of India, for providing the rainfall data.

\section{References}

Andreae M O and Merlet P 2001 Emission of trace gases and aerosols from biomass burning; Global Biogeochem. Cycles 15 955-966.

Arino O, Simon M, Piccolini I and Rosaz J M 2001 The ERS-2 ATSR-2 World Fire Atlas and the ERS-2 ATSR2 World Burnt Surface Atlas projects; Paper presented at 8th ISPRS conference on Physical Measurement and Signatures in Remote Sensing, European Space Agency, Aussois, France.

Arino O, Plummer S and Defrenne D 2005 Fire disturbance: The 10 years time series of the ATSR World Fire Atlas; Proceedings of the MERIS-AATSR Symposium, ESA Publication SP-597.

Arino O, Plummer S and Casadio S 2007 Fire disturbance: The 12 years time series of the ATSR World Fire Atlas; Proceedings of ENVISAT symposium 200\%, ESA Publication, SP-636.

Arino O, Casadio S and Serpe D 2012 Global night-time fire season timing and fire count trends using the ATSR instrument series; Remote Sens. Environ. 116 226-238, doi: 10.1016/j.rse.2011.05.025.

Bond T C, Streets D G, Yarber K F, Nelson S M, Woo J-H and Klimont Z 2004 A technology-based global inventory of black and organic carbon emissions from combustion; J. Geophys. Res. 109 D14203, doi: 10.1029/2003JD003697.

Buongiorno A, Arino O, Zehner C, Colagrande P and Goryl P 1997 ERS-2 monitors exceptional fire event; Earth Obs. Q. $561-6$.

Casadio S, Arino O and Serpe D 2012 Gas flaring monitoring from space using the ATSR instrument series; Remote Sens. Environ. 116 239-249.

Christopher S A, Kliche D V, Chou J and Welch R M 1996 First estimates of the radiative forcing of aerosols generated from biomass burning using satellite data; $J$. Geophys. Res. 101(D16) 21,265-21,273.
Crutzen P J and Andreae M O 1990 Biomass burning in the tropics: Impact on atmospheric chemistry and biogeochemical cycles; Science 250(4988) 1669-1678.

Curtis S and Adler R 2000 ENSO indexes based on patterns of satellite-derived precipitation; J. Climate 13 27862793.

Dozier J 1981 A method for satellite identification of surface temperature fields of subpixel resolution; Remote Sens. Environ. 11 221-229.

Duncan B N, Martin R V, Yevitch A C R and Logan J A 2003 Interannual and seasonal variability of biomass burning emissions constrained by satellite observations; J. Geophys. Res. 108(D2) 4040, doi: 10.1029/ 2002JD002378.

Folkins I, Chatfield R, Baumgardner D and Proffitt M 1997 Biomass burning and deep convection in southeastern Asia: Results from ASHOE/MAESA; J. Geophys. Res. 102 13,291-13,299.

Giglio L, Descloitres J, Justice C O and Kaufman Y J 2003 An enhanced contextual fire detection algorithm for MODIS; Remote Sens. Environ. 87 273-282.

Giriraj A, Babar S, Jentsch A, Sudhakar S and Murthy M S R 2010 Tracking fires in India using Advanced Along Track Scanning Radiometer (A)ATSR data; Remote Sens. 2 591-610.

Habib G, Venkataraman C, Chiapello I, Ramachandran S, Boucher O and Reddy M S 2006 Seasonal and interannual variability in absorbing aerosols over India derived TOMS: Relationship to regional meteorology and emissions; Atmos. Environ. 40 1909-1921, doi: 10.1016/j.atmosenv.2005.07.077.

Hao W M and Liu M H 1994 Spatial and temporal distribution of biomass burning; Global Biogeochem. Cycles $\mathbf{8}$ 495-503.

Ito A and Penner J E 2004 Global estimates of biomass burning emissions based on satellite imagery for the year 2000; J. Geophys. Res. 109 D14S05, doi: 10.1029/ 2003JD004423.

Kaufman Y J, Justice C O, Flynn L P, Kendall J D, Prins E M, Giglio L, Ward D E, Menzel W P and Setzer A W 1998 Potential global fire monitoring from EOSMODIS; J. Geophys. Res. 103 32,215-32,238.

Kharol S K and Badarinath K V S 2006 Impact of biomass burning on aerosol properties over tropical urban region of Hyderabad, India; Geophys. Res. Lett. 33 L20801, doi: 10.1029/2006GL026759.

Kumar R, Naja M, Pfister G G, Barth M C, Wiedinmyer C and Brasseur G P 2012 Simulations over South Asia using the weather research and forecasting model with chemistry (WRF-Chem): Chemistry evaluation and initial results; Geosci. Model Dev. 5 619-648.

Lal S 2007 Trace gases over the Indian region; Indian J. Radio Space Phys. 36 556-570.

Legg C A and Laumonier Y 1999 Fires in Indonesia, 1997: A remote sensing perspective; Ambio. 28(6) 479-485.

Lelieveld $\mathrm{J}$ et al. 2001 The Indian Ocean Experiment: Widespread air pollution from south and southeast Asia; Science 291 1031-1036.

Levine J S 2000 Global biomass burning: A case study of the gaseous and particulate emissions released to the atmosphere during the 1997 fires in Kalimantan and Sumatra, Indonesia; In: Biomass burning and its inter-relationships with the climate system (eds) Innes J L, Beniston M and Verstraete M M (Norwell, Mass: Kluwer Acad.) pp. 15-31.

Mieville A, Granier C, Liousse C, Guillaume B, Mouillot F, Lamarque J F, Grégoire J M and Pétron G 2010 Emissions of gases and particles from biomass burning during the 20th century using satellite data and a historical reconstruction; Atmos. Environ. 44 1469-1477. 
Sahu L K and Lal S 2006 Distributions of C2-C5 NMHCs and related trace gases at a tropical urban site in India; Atmos. Environ. 40 880-891.

Sahu L K and Sheel V 2014 Spatio-temporal variation of biomass burning sources over south and southeast Asia; J. Atmos. Chem. 71(1) 1-19, doi: 10.1007/s10874-0139275-4.

Sahu L K, Lal S and Venkataramani S 2006 Distributions of $\mathrm{O}_{3}, \mathrm{CO}$ and hydrocarbons over the Bay of Bengal: A study to assess the role of transport from southern India and marine regions during September-October 2002; Atmos. Environ. 40(24) 4633-4645, doi: 10.1016/j. atmosenv.2006.02.037.

Sahu L K, Lal S and Venkataramani S 2011 Seasonality in the latitudinal distributions of NMHCs over Bay of Bengal; Atmos. Environ. 45 2356-2366.

Sahu L K, Kondo Y, Moteki N, Takegawa N, Zhao Y, Cubison M J, Jimenez J -L, Vay S, Diskin G S, Wisthaler A, Mikoviny T, Huey L G, Weinheimer A J J and Knapp D 2012 Emission characteristics of black carbon in anthropogenic and biomass burning plumes over California during ARCTAS-CARB 2008; J. Geophys. Res. 117 D16302, doi: $10.1029 / 2011 J D 017401$.

Sheel V, Sahu L K, Kajino M, Deushi M, Stein O and Nedelec P 2014 Seasonal and interannual variability of carbon monoxide based on MOZAIC observations, MACC reanalysis, and model simulations over an urban site in India; J. Geophys. Res. Atmos. 119 9123-9141, doi: 10.1002/2013JD021425.

Singh C P and Panigrahy S 2011 Characterisation of residue burning from agricultural system in India using spacebased observations; J. Indian Soc. Remote Sens. 39(3) 423-429.
Singh C P, Singh R P and Panigrahy S 2009 Assessment of biomass burning and $\mathrm{CO}$ emission over India using space-borne measurements, Proc. of Geomatics-2009, National Conference on Geomatics and Impact of Climate Change with Specific reference to Mountain Ecosystem, Dehradun, India, 3-5th February 2009.

Streets D G, Yarber K F, Woo J-H and Carmichael G R 2003 Biomass burning in Asia: Annual and seasonal estimates and atmospheric emissions; Global Biogeochem. Cycles 17(4) 1099, doi: 10.1029/2003GB002040.

van der Werf G R, Randerson J T, Giglio L, Collatz G J, Kasibhatla P S and Arellano A F Jr 2006 Interannual variability of global biomass burning emissions from 1997 to 2004; Atmos. Chem. Phys. Disc. 6 31753226 .

van der Werf G R, Randerson J T, Giglio L, Collatz G J, Mu M, Kasibhatla P S, Morton D C, DeFries R S, Jin Y and van Leeuwen T T 2010 Global fire emissions and the contribution of deforestation, savanna, forest, agricultural, and peat fire 1997-2009; Atmos. Chem. Phys. 10 11,70711,735, doi: 10.5194/acp-10-11707-2010.

Venkataraman C, Habib G, Kadamba D, Shrivastava M, Leon J-F, Crouzille B, Boucher O and Streets D G 2006 Emissions from open biomass burning in India: Integrating the inventory approach with high-resolution Moderate Resolution Imaging Spectroradiometer (MODIS) activefire and land cover data; Global Biogeochem. Cycles 20 GB2013, doi: 10.1029/2005GB002547.

Wooster M J, Roberts G and Perry G L W 2005 Retrieval of biomass combustion rates and totals from fire radiative power observations: FRP derivation and calibration relationships between biomass consumption and fire radiative energy release; J. Geophys. Res. 110 D24311, 1-24. 